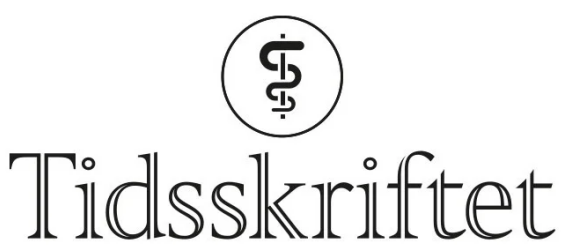

DEN NORSKE LEGEFORENING

\title{
Covid-19 rapportert til Folkehelseinstituttet de første seks ukene av epidemien
}

ORIGINALARTIKKEL

\author{
ELINA SEPPÄLÄ \\ elina.seppala@fhi.no \\ Område for smittevern, miljø og helse \\ Folkehelseinstituttet \\ og \\ Europeisk feltepidemiologiutdanning (EPIET) \\ Det europeiske smittevernbyrået (ECDC) \\ Solna, Sverige \\ Hun har bidratt med utforming av studien, innsamling, analysering og tolkning av data, \\ litteraturs $ø \mathrm{k}$, utarbeiding og godkjenning av innsendte manuskript. \\ Elina Seppälä er cand.med. og rådgiver. \\ Forfatteren har fylt ut ICMJE-skjemaet og oppgir ingen interessekonflikter.
}

\section{RAGNHILD TØNNESSEN}

Område for smittevern, miljø og helse

Folkehelseinstituttet

Hun har bidratt med utforming av studien, innsamling og tolkning av data, utarbeiding og godkjenning av innsendte manuskript.

Ragnhild Tønnessen er cand.med.vet., ph.d. og seniorrådgiver.

Forfatteren har fylt ut ICMJE-skjemaet og oppgir ingen interessekonflikter.

\section{LAMPRINI VENETI}

Område for smittevern, miljø og helse

Folkehelseinstituttet

Hun har bidratt med utforming av studien, innsamling, analysering og tolkning av data, utarbeiding og godkjenning av innsendte manuskript.

Lamprini Veneti er M.Sc. og rådgiver.

Forfatteren har fylt ut ICMJE-skjemaet og oppgir ingen interessekonflikter.

\section{TRINE HESSEVIK PAULSEN}

Område for smittevern, miljø og helse

Folkehelseinstituttet

Hun har bidratt med utforming av studien, innsamling og tolkning av data, utarbeiding og godkjenning av innsendte manuskript.

Trine Hessevik Paulsen er lege.

Forfatteren har fylt ut ICMJE-skjemaet og oppgir ingen interessekonflikter. 


\section{ANNEKE STEENS}

Område for smittevern, miljø og helse

Folkehelseinstituttet

Hun har bidratt med utforming av studien, innsamling og tolkning av data, utarbeiding og godkjenning av innsendte manuskript.

Anneke Steens er ph.d. og forsker.

Forfatteren har fylt ut ICMJE-skjemaet og oppgir ingen interessekonflikter.

\section{ROBERT WHITTAKER}

Område for smittevern, miljø og helse

Folkehelseinstituttet

og

Europeisk feltepidemiologiutdanning (EPIET)

Det europeiske smittevernbyrået (ECDC)

Solna, Sverige

Han har bidratt med utforming av studien, innsamling og tolkning av data, litteratursøk, utarbeiding og godkjenning av innsendte manuskript.

Robert Whittaker er M.Sc. og forsker.

Forfatteren har fylt ut ICMJE-skjemaet og oppgir ingen interessekonflikter.

\section{KAROLINE BRAGSTAD}

Område for smittevern, miljø og helse

Folkehelseinstituttet

Hun har bidratt med utforming av studien, innsamling og tolkning av data, utarbeiding og godkjenning av innsendte manuskript.

Karoline Bragstad er ph.d. og seniorforsker.

Forfatteren har fylt ut ICMJE-skjemaet og oppgir ingen interessekonflikter.

\section{JACOB DAG BERILD}

Område for smittevern, miljø og helse

Folkehelseinstituttet

Han har bidratt med utforming av studien, innsamling og tolkning av data, utarbeiding og godkjenning av innsendte manuskript.

Jacob Dag Berild er lege.

Forfatteren har fylt ut ICMJE-skjemaet og oppgir ingen interessekonflikter.

\section{ASTRID LOUISE LØVLIE}

Område for smittevern, miljø og helse

Folkehelseinstituttet

Hun har bidratt med utforming av studien, innsamling og tolkning av data, utarbeiding og godkjenning av innsendte manuskript.

Astrid Louise Løvlie er M.Phil. og seniorrådgiver.

Forfatteren har fylt ut ICMJE-skjemaet og oppgir ingen interessekonflikter.

\section{UMAER NASEER}

Område for smittevern, miljø og helse

Folkehelseinstituttet

Han har bidratt med utforming av studien, innsamling og tolkning av data, utarbeiding og godkjenning av innsendte manuskript.

Umaer Naseer er ph.d. og seniorforsker.

Forfatteren har fylt ut ICMJE-skjemaet og oppgir ingen interessekonflikter.

\section{EMILY MACDONALD}

Område for smittevern, miljø og helse Folkehelseinstituttet

Hun har bidratt med utforming av studien, innsamling og tolkning av data, utarbeiding og godkjenning av innsendte manuskript.

Emily MacDonald er M.Phil. og seniorrådgiver.

Forfatteren har fylt ut ICMJE-skjemaet og oppgir ingen interessekonflikter. 


\section{LINE VOLD}

Område for smittevern, miljø og helse

Folkehelseinstituttet

Hun er leder av Folkehelseinstituttets utbruddsgruppe for covid-19 og har bidratt med tolkning av data, utarbeiding og godkjenning av innsendte manuskript.

Line Vold er cand.med.vet., ph.d. og avdelingsdirektør.

Forfatteren har fylt ut ICMJE-skjemaet og oppgir ingen interessekonflikter.

Ragnhild Tønnessen, Lamprini Veneti og Trine Hessevik Paulsen har bidratt i like stor grad til denne artikkelen.

\section{BAKGRUNN}

Det første tilfellet av påvist SARS-CoV-2 i Norge ble bekreftet 26. februar 2020. Etter forsterkede råd om generelle smitteverntiltak i begynnelsen av utbruddet ble det 12. mars iverksatt omfattende nasjonale kontrolltiltak, og testingen ble rettet mot alvorlig syke. Her beskriver vi de seks første ukene av utbruddet i Norge, sett i lys av testkriterier og kontrolltiltak.

\section{MATERIALE OG METODE}

Vi beskrev alle laboratoriebekreftede covid-19-tilfeller rapportert til tre forskjellige overvåkingssystemer ved Folkehelseinstituttet frem t.o.m. 5. april 2020. Tilfellene rapportert frem til og med 12. mars ble sammenlignet med tilfellene rapportert fra og med 13. mars.

\section{RESULTATER}

Frem t.o.m. 12. mars var 1128 tilfeller rapportert. Disse hadde en median alder på 47 år, $64 \%$ var menn, $66 \%$ hadde reist utenlands, $6 \%$ var innlagt i sykehus ved rapportering og $<1 \%$ døde. Blant de 4742 tilfellene rapportert f.o.m. 13. mars, var median alder 48 år, $47 \%$ var menn, $18 \%$ hadde reist utenlands, $15 \%$ var innlagt i sykehus og $3 \%$ døde.

\section{FORTOLKNING}

Fordelingen av tilfellene før og etter 12. mars reflekterer ulike faser av utbruddet, men må tolkes i lys av testkriterier, testaktivitet, kontrolltiltak og egenskaper ved overvåkingssystemene.

\section{HOVEDFUNN}

Frem til og med 12. mars ble 1128 tilfeller av laboratoriebekreftet covid-19 rapportert til Folkehelseinstituttet.

Median alder var 47 år, 64\% var menn, 66 \% hadde reist utenlands, 6 \% var innlagt i sykehus ved rapportering og $<1 \%$ døde.

Blant 4742 tilfeller rapportert 13.3-5.4.2020 var median alder 48 år, andelen menn var redusert til $47 \%$, færre hadde reist utenlands (18\%) og en høyere andel var innlagt (15\%) eller døde (3\%).

En økning i antall personer med alvorlig lungebetennelse av ukjent årsak ble rapportert fra Wuhan i Kina 31. desember 2019. Et nytt koronavirus, senere kalt SARS-CoV-2, ble identifisert av kinesiske helsemyndigheter 7 . januar 2020 som årsaken til sykdommen nå kjent som covid-19(1). Viruset spredte seg raskt, og Verdens helseorganisasjon erklærte utbruddet som en internasjonal folkehelsekrise 30. januar og deretter en pandemi 11. mars $2020(\underline{2})$. 
I Norge ble testing for SARS-CoV-2 i begynnelsen forbeholdt nærkontakter av bekreftede tilfeller og personer som kom tilbake fra land med utbredt smitte. Det første tilfellet av påvist SARS-CoV-2-infeksjon ble bekreftet 26. februar. I starten av utbruddet forsterket man råd om generelle smitteverntiltak, som for eksempel å holde seg hjemme ved sykdom og gjennomføring av god hånd- og hostehygiene. 12. mars ble det innført omfattende nasjonale kontrolltiltak for å redusere smitteutbredelse og opprettholde tilstrekkelig behandlingskapasitet i sykehusene. Disse inkluderte blant annet stenging av barnehager, skoler, kultur- og idrettsarrangementer, virksomheter i serveringsbransjen og virksomheter med en-til-en-kontakt med kundene (f.eks. fysioterapeuter og frisører) samt karantene ved innreise til Norge (3).

Samtidig ble testkriteriene endret for å sikre diagnostikk ved alvorlig sykdom. Endringer i testkriterier, implementering av kontrolltiltak og andre viktige datoer under begynnelsen av covid-19-utbruddet i Norge er presentert i figur 1. Fra og med 13. mars inkluderte testkriteriene pasienter med symptomer forenlig med covid-19 og økt risiko for å utvikle alvorlig sykdom, pasienter i helseinstitusjoner med akutt luftveisinfeksjon og helsepersonell med akutt luftveisinfeksjon (ramme 1).

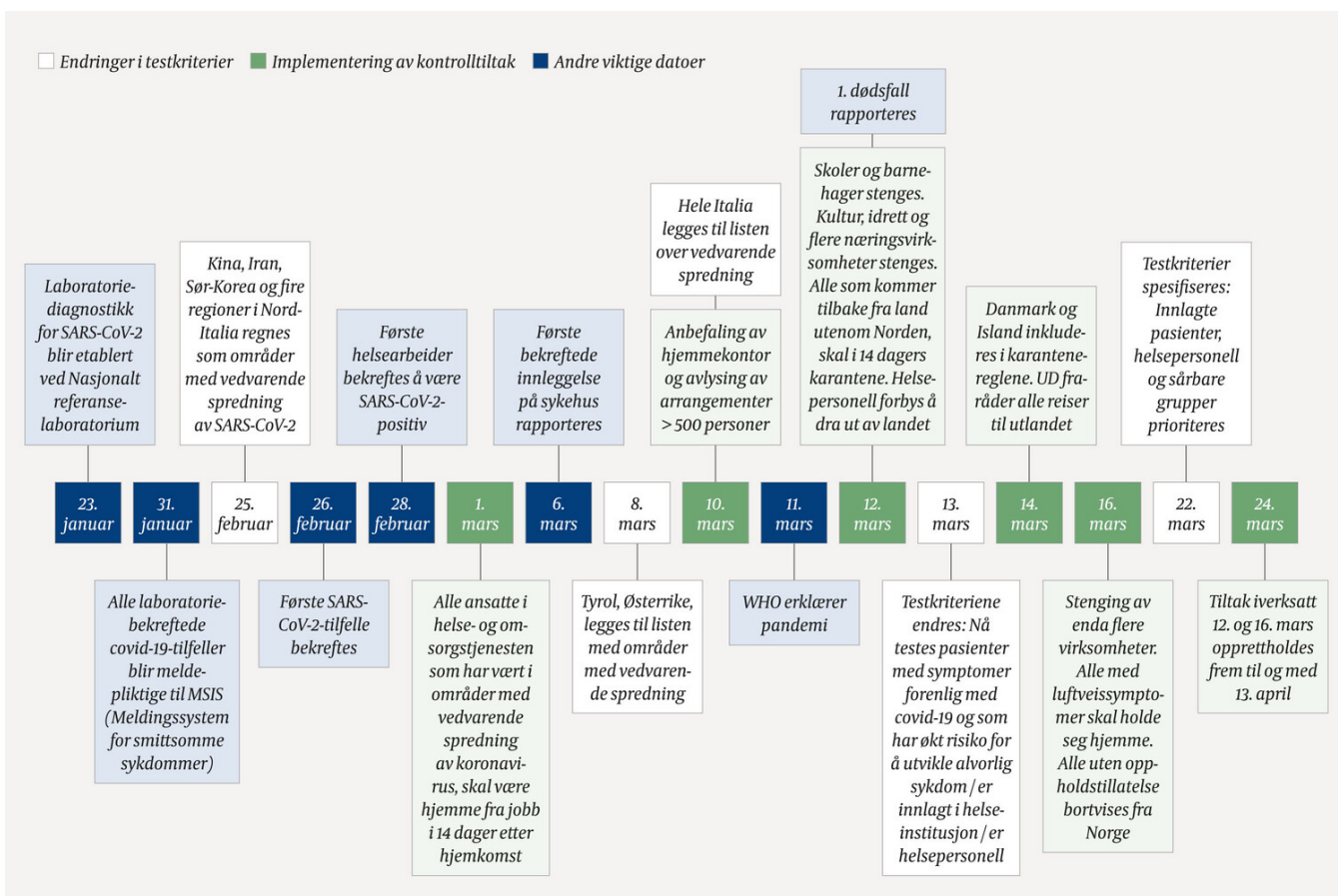

Figur 1 Endringer i testkriterier, implementering av kontrolltiltak og andre viktige datoer under begynnelsen av covid-19-utbruddet i Norge januar-mars 2020. Tidslinjen er ikke uttømmende.

Ramme 1 Testkriterier for SARS-CoV-2 i Norge 23.1-5.4.2020.

\section{3. januar-12. mars}

Personer med akutt luftveisinfeksjon (minst ett av følgende: hoste, kortpustethet, feber (sår hals var inkludert noen dager i februar)) som i løpet av 14 dager innen symptomdebut oppfylte minst ett av følgende kriterier:

- har vært i et område med spredning av covid-19

- har vært i nærkontakt med et bekreftet tilfelle av covid-19

- har pleiet en pasient, håndtert prøvemateriale fra eller på annen måte hatt tilsvarende nærkontakt med en person som er bekreftet syk med covid-19 (innført 3 . mars), uavhengig av om beskyttelsesutstyr er benyttet (lagt til 9. mars)

- har vært på reise utenom Norden og er ansatt i helsetjenesten (innført 9. mars)

- har vært på reise utenom Norden og er innlagt i helseinstitusjon (innført 10. mars) 


\section{3. mars-5. april}

Personer med akutt luftveisinfeksjon (minst ett av følgende: hoste, kortpustethet, feber) som var:

- i behov for innleggelse

- innlagt/bosatt i helseinstitusjon

- ansatt i helsetjenesten med pasientnært arbeid

- tilhørende sårbar gruppe selv ved milde symptomer (fra 20. mars endret til personer $>65$ år som har underliggende kronisk sykdom) og nærkontakt til en person med bekreftet covid-19 (der smitteoppsporing var indisert, gjaldt til 19. mars)

Testing ble prioritert i denne rekkefølgen f.o.m. 22. mars

Folkehelseinstituttet overvåker utbruddet av covid-19 i Norge og publiserer fortløpende nasjonal statistikk om testing og testresultater for SARS-CoV-2, antall covid-19-tilfeller meldt til Meldingssystem for smittsomme sykdommer (MSIS), antall bekreftede tilfeller innlagt i sykehus og intensivavdeling og covid-19-assosierte dødsfall (4).

I denne artikkelen kombinerer vi data fra ulike datakilder i overvåkingen for å sammenligne de laboratoriebekreftede covid-19-tilfellene i Norge før og etter kontrolltiltak ble innført 12. mars og t.o.m. 5. april. Vi drøfter hvordan endringer i testkriteriene og tiltakene kan ha påvirket utbruddet i befolkningen og funnene fra overvåkingen.

\section{Materiale og metode}

\section{LABORATORIEDIAGNOSTIKK, TESTKRITERIER OG OVERVÅKING}

Laboratoriediagnostikk for SARS-CoV-2 ble etablert 23. januar ved Nasjonalt referanselaboratorium ved Folkehelseinstituttet. Den primære testen var en sanntids revers transkriptase-polymerasekjedereaksjonstest (RT-PCR) for deteksjon av E-genet (5), hovedsakelig utført på materiale fra svelg og dyp neseprøve. Med høy sensitivitet (opptil 99,9\%), men litt lavere spesifisitet (ca. 80 \%) kan metoden gi falskt positive svar dersom man tester mange personer med lav sannsynlighet for å være SARS-CoV-2-smittet (ㅁ). Metoder for testing ble etablert ved de fleste norske medisinske mikrobiologiske laboratorier innen fă uker. Testkriteriene for ulike tidsperioder er vist i ramme 1.

De fleste laboratoriene som testet for SARS-CoV-2 rapporterte daglig antall testede med opplysninger om testresultat og prøvetakingsdato til laboratorieovervåkingssystemet ved Nasjonalt referanselaboratorium. Et mindretall laboratorier rapporterte kumulativt antall tester uten nøyaktig prøvetakingsdato. Frem til 30. mars inneholdt datasettet vårt informasjon om antall tester og antall positive tester, mens det fra og med 1. april inneholdt informasjon om antall testede personer og antall personer som testet positivt, i tråd med overvåkingsdata publisert på Folkehelseinstituttets nettside.

Frem t.o.m. 5. april 2020 var kommuneoverlegene pliktige til å varsle alle laboratoriebekreftede covid-19-tilfeller til Folkehelseinstituttet per telefon (7-9.). Et bekreftet tilfelle var definert som en person med påvist SARS-CoV-2-infeksjon uavhengig av klinisk bilde. Opplysninger om alder, kjønn, smittested, type eksponering, eventuell symptomdebut, dato for testing og eventuell sykehusinnleggelse ble samlet inn. Type eksponering var definert som uspesifisert lokal smitte hvis tilfellet ikke var smittet i utlandet eller ikke var nærkontakt av et bekreftet tilfelle, men hvor det var holdepunkter for lokal smitte. Resterende tilfeller ble kategorisert som ukjent eksponering.

Opplysningene ble ført inn i Utbruddsregisteret, som ble opprettet for å få rask oversikt over utbruddet og for å kunne iverksette tiltak og ivareta internasjonale rapporteringsforpliktelser. For de 243 første tilfellene varslet til Folkehelseinstituttet t.o.m. 9. mars ble varslende kommuneoverlege også bedt om å fylle ut et spørreskjema med mer 
utvidede opplysninger, bl.a. om eksponering og yrke. Informasjon fra spørreskjemaene ble registrert i Utbruddsregisteret. Covid-19-assosierte dødsfall ble varslingspliktige f.o.m. 13. mars (모). Informasjonen ble lagt inn i Utbruddsregisteret, der også det første kjente dødsfallet 12. mars ble registrert.

I tillegg til telefonisk varsling ble alle laboratoriebekreftede tilfeller meldepliktige til MSIS fra 31. januar 2020. Leger og laboratorier rapporterte epidemiologisk, klinisk og mikrobiologisk informasjon ved bruk av standard MSIS-meldingsskjema $(\underline{8}, \underline{10}, \underline{11})$. Innsamling av data til laboratorieovervåkingssystemet, Utbruddsregisteret og MSIS forløp parallelt (9.).

DATABEHANDLING OG ANALYSE

Vi inkluderte opplysninger om alle tilfeller rapportert til Utbruddsregisteret og MSIS frem t.o.m. 5. april 2020, med data om eventuelle dødsfall blant disse tilfellene meldt t.o.m. 7 . mai 2020. Vi koblet MSIS-dataene med data fra Utbruddsregisteret via fødselsnummer for å maksimere komplettheten av antall tilfeller og variabler. Var det avvik mellom Utbruddsregisteret og MSIS, skulle data fra MSIS prioriteres, fordi denne var den primære datakilden brukt til overvåking. Der det ikke var informasjon om sykehusinnleggelse i Utbruddsregisteret, antok man at personen ikke var innlagt i sykehus, med mindre MSIS hadde annen informasjon.

Vi beskrev tilfellene ut fra demografi, geografi og alvorlighet for hele perioden 26 . februar 5. april 2020 og delte inn i periode A (t.o.m. 12. mars) og periode B (f.o.m. 13. mars), basert på prøvedatoen. For å lage påvisningsrater, definert som antall rapporterte tilfeller per 100 ooo innbyggere, ble befolkningsdata hentet fra Statistisk sentralbyrå (www.ssb.no).

Fra laboratorieovervåkingssystemet inkluderte vi opplysninger om alle prøver tatt t.o.m. 5 april. Andel positive tester ble beregnet som antall positive tester delt på det totale antallet tester. For noen av tilfellene som ble testet i begynnelsen av april, og som inngår $\mathrm{i}$ laboratoriedatasettet, ble melding til MSIS og varsling per telefon til Utbruddsregisteret først utført etter 5. april. Disse er dermed ikke med i materialet derfra.

Dataanalyse ble gjort ved bruk av Excel og Stata SE 16.o. Kart ble laget ved hjelp av QGIS versjon 3.10.0-A Coruña.

\section{ETISKE VURDERINGER}

Dataene ble rapportert til Folkehelseinstituttet i henhold til norsk lovgivning, uten behov for samtykke $(7, \underline{7}, \underline{12}, \underline{13})$. Prosjektet har etisk godkjenning fra REK (referansenummer 136964), og Folkehelseinstituttet gjennomførte og godkjente en personvernkonsekvensvurdering.

\section{Resultater}

Per 5. april var 5870 covid-19-tilfeller registrert i Utbruddsregisteret og/eller MSIS. 4629 tilfeller var registrert i begge registre, 1125 var bare meldt til MSIS og 116 var bare registrert i Utbruddsregisteret. Den første toppen i antall påviste tilfeller per dag var 9.-10. mars (figur 2), mens majoriteten av tilfellene (4742, 81 \%) ble påvist etter 12. mars. 


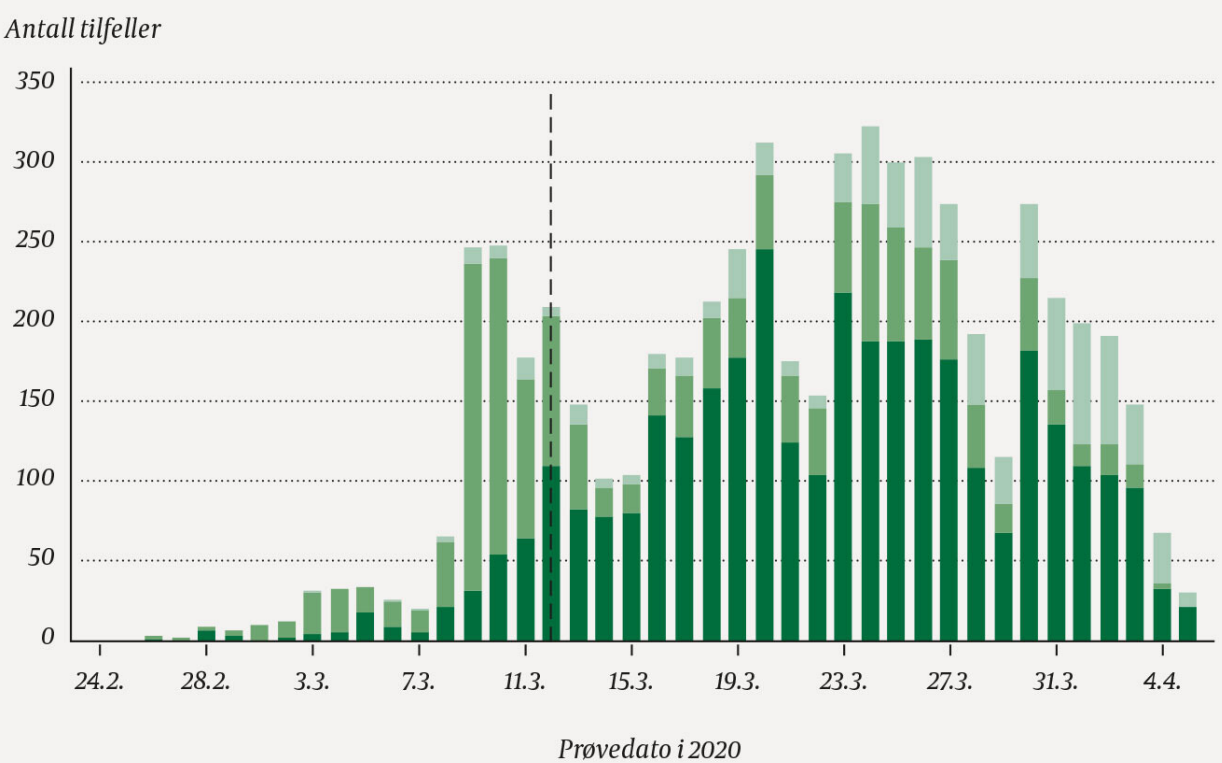

Figur 2 Tilfeller av covid-19 meldt til MSIS og/eller varslet til Folkehelseinstituttet etter prøvedato og smittested, Norge 24.2.-5.4.2020. Den stiplede linjen markerer 12. mars, dagen da omfattende nasjonale kontrolltiltak ble iverksatt og testkriteriene ble vesentlig endret. Totalt antall tilfeller var 5 870. Noen tilfeller testet 4.-5.april 2020 hadde enda ikke blitt rapportert til Folkehelseinstituttet per 5. april.

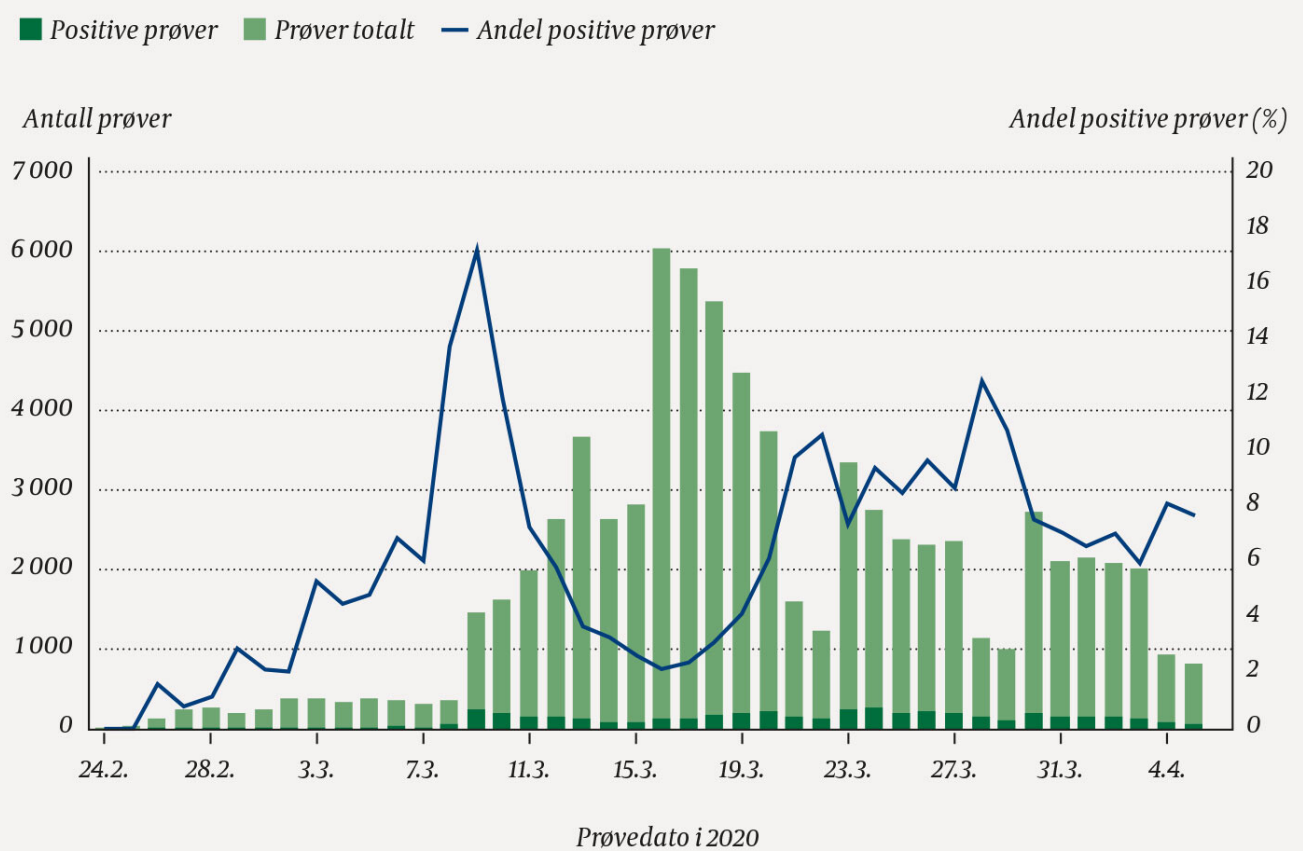

Figur 3 Totalt antall prøver (f.o.m. 1. april: antall personer testet), antall og andel prøver (f.o.m. 1. april: personer testet) positive for SARS-CoV-2 rapportert til laboratorieovervåkingssystemet i Norge i perioden 24.2.-5.4.2020. Totalt antall prøver med nøyaktig prøvetakingsdato var 95613 , hvorav 5369 var positive.

Totalt 119435 prøver (2 225 prøver per 100 ooo innbyggere) ble registrert i laboratorieovervåkingssystemet t.o.m. 5. april, hvorav 6203 (5\%) var positive for SARS-CoV2. Basert på tall fra laboratoriene som oppga prøvetakingsdato, var andel positive prøver høyest 8.-10. mars (11-17\%) (figur 3), mens det høyeste antallet prøver ble registrert 16.-20. mars. 
Median alder for alle tilfellene var 48 år (min-maks o-102), og 2939 (50\%) var menn. Kjønnsfordelingen endret seg over tid, der menn utgjorde $64 \%$ av tilfellene i periode A og 47 \% i periode B (tabell 1). Median alder var henholdsvis 47 år og 48 år i de to periodene, og andelen tilfeller i alderen 60 år eller eldre økte fra $15 \%$ til 29\% (tabell 2).

\section{Tabell 1}

Beskrivelse av covid-19-tilfellene etter prøvetakingsperiode i Norge 24.2.-5.4.2020. Antall (\%) dersom annet ikke er angitt. Q1-Q3: nedre kvartil til øvre kvartil

\begin{tabular}{|c|c|c|c|}
\hline & $\begin{array}{l}\text { 24. februar } \\
-5 \cdot \text { april }(n=5 \\
870)\end{array}$ & $\begin{array}{l}\text { Til og med } 12 . \\
\text { mars }(n= \\
1128)\end{array}$ & $\begin{array}{l}\text { Fra og med } 13 . \\
\operatorname{mars}(n=4742)\end{array}$ \\
\hline Alder (median, $\mathrm{Q}_{1}-\mathrm{Q}_{3}$ ) & $48(33-60)$ & $47(35-55)$ & $48(33-62)$ \\
\hline \multicolumn{4}{|l|}{ Kjønn } \\
\hline Kvinne & $2931(49,9)$ & $403(35,7)$ & $2528(53,3)$ \\
\hline Mann & $2939(50,1)$ & $725(64,3)$ & $2214(46,7)$ \\
\hline \multicolumn{4}{|l|}{ Smitteland } \\
\hline Norge & $3458(58,9)$ & $331(29,3)$ & $3127(65,9)$ \\
\hline Utlandet & $1613(27,5)$ & $747(66,2)$ & $866(18,3)$ \\
\hline Ukjent & $799(13,6)$ & $50(4,4)$ & $749(15,8)$ \\
\hline \multicolumn{4}{|l|}{ Type eksponering } \\
\hline Utenlandsreise & $1613(27,5)$ & $747(66,2)$ & $866(18,3)$ \\
\hline Nærkontakt med bekreftet tilfelle & $1410(24,0)$ & $218(19,3)$ & $1192(25,1)$ \\
\hline Uspesifisert lokal smitte & $1357(23,1)$ & $96(8,5)$ & $1261(26,6)$ \\
\hline Ukjent & $1490(25,4)$ & $67(5,9)$ & $1423(30,0)$ \\
\hline \multicolumn{4}{|l|}{ Helsepersonell } \\
\hline Ja & $1222(20,8)$ & $61(5,4)$ & $1161(24,5)$ \\
\hline Nei & $2293(39,1)$ & $259(23,0)$ & $2034(42,9)$ \\
\hline Ukjent & $2355(40,1)$ & $808(71,6)$ & $1547(32,6)$ \\
\hline \multicolumn{4}{|l|}{ Sykehusinnlagt ved rapportering } \\
\hline Ja & $750(12,8)$ & $63(5,6)$ & $687(14,5)$ \\
\hline Nei & $4710(80,2)$ & $1039(92,1)$ & $3671(77,4)$ \\
\hline Ukjent & $410(7,0)$ & $26(2,3)$ & $384(8,1)$ \\
\hline Rapportert død per 7. mai & $158(2,7)$ & $5(0,4)$ & $153(3,2)$ \\
\hline \multicolumn{4}{|l|}{ Tidsintervaller, dager (median, $\mathrm{Q}_{1}-\mathrm{Q}_{3}$ ) } \\
\hline Symptomdebut til testing $(n=4882)$ & $4(2-8)$ & $2(1-4)$ & $5(3-9)$ \\
\hline Testing til rapportering $(n=5870)$ & $1(1-2)$ & $1(1-2)$ & $1(1-2)$ \\
\hline $\begin{array}{l}\text { Symptomdebut til sykehusinnleggelse } \\
(\mathrm{n}=312)^{1}\end{array}$ & $7(4-10)$ & $7(5,5-9)$ & $7(4-10)$ \\
\hline
\end{tabular}




\begin{tabular}{|c|c|c|c|}
\hline & $\begin{array}{l}\text { 24. februar } \\
-5 \cdot \text { april }(n=5 \\
870)\end{array}$ & $\begin{array}{l}\text { Til og med } 12 . \\
\text { mars }(n= \\
1128)\end{array}$ & $\begin{array}{l}\text { Fra og med } 13 . \\
\operatorname{mars}(n=4742)\end{array}$ \\
\hline Symptomdebut til død $(\mathrm{n}=145)^{2}$ & $13(9-21)$ & $21(9-27)$ & $13(9-20)$ \\
\hline
\end{tabular}

${ }^{1}$ Dato var tilgjengelig for 20 pasienter testet frem til og med 12. mars og for 292 pasienter testet fra 13. mars

${ }^{2}$ Dato var tilgjengelig for 5 pasienter testet frem til og med 12. mars og for 140 pasienter testet fra 13. mars.

\section{Tabell 2}

Tilfeller av covid-19 registrert i Folkehelseinstituttets utbruddsregister og/eller i MSIS samt antall testede prøver og antall positive prøver for SARS-CoV-2 per 100 ooo innbyggere i Norge i perioden 24.2.-5·4.2020, fordelt på aldersgruppe og prøvetakingsperiode.

\begin{tabular}{|c|c|c|c|c|c|c|c|}
\hline \multirow{3}{*}{$\begin{array}{l}\text { Aldersgruppe } \\
\\
0-9\end{array}$} & \multirow{3}{*}{ 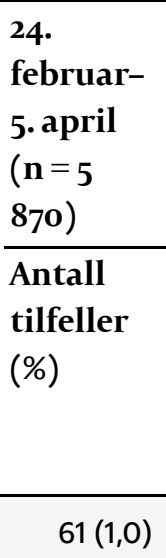 } & \multicolumn{3}{|c|}{$\begin{array}{l}\text { T.o.m. 12. mars } \\
(\mathbf{n}=\mathbf{1 1 2 8})\end{array}$} & \multicolumn{3}{|c|}{$\begin{array}{l}\text { F.o.m. 13. mars } \\
(n=4742)\end{array}$} \\
\hline & & \multirow[t]{2}{*}{$\begin{array}{l}\text { Antall } \\
\text { tilfeller } \\
(\%)\end{array}$} & $\begin{array}{l}\text { Totalt } \\
\text { antall } \\
\text { prøver } \\
\text { per 10o } \\
\text { ooo }\end{array}$ & \multirow{2}{*}{ 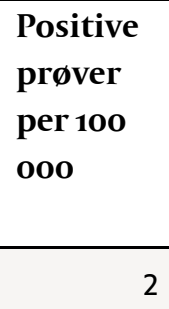 } & \multirow{2}{*}{$\begin{array}{l}\begin{array}{l}\text { Antall } \\
\text { tilfeller } \\
(\%)\end{array} \\
47(1,0)\end{array}$} & $\begin{array}{l}\text { Totalt } \\
\text { antall } \\
\text { prøver } \\
\text { per 10o } \\
\text { ooo }\end{array}$ & $\begin{array}{l}\text { Positive } \\
\text { prøver } \\
\text { per 10o } \\
\text { ooo }\end{array}$ \\
\hline & & & 94 & & & 202 & 7 \\
\hline $10-19$ & $249(4,2)$ & $42(3,7)$ & 159 & 5 & $207(4,4)$ & 242 & 25 \\
\hline $20-29$ & $784(13,3)$ & $121(10,7)$ & 208 & 14 & $\begin{array}{r}663 \\
(14,0)\end{array}$ & 1529 & 71 \\
\hline $30-39$ & $947(16,1)$ & $\begin{array}{r}180 \\
(16,0)\end{array}$ & 278 & 20 & $\begin{array}{r}767 \\
(16,2)\end{array}$ & 1959 & 83 \\
\hline |40-49 & $\begin{array}{r}1109 \\
(18,9)\end{array}$ & $\begin{array}{r}297 \\
(26,3)\end{array}$ & 306 & 34 & $812(17,1)$ & 1756 & 91 \\
\hline 50-59 & $\begin{array}{r}1198 \\
(20,4)\end{array}$ & $\begin{array}{r}310 \\
(27,5)\end{array}$ & 299 & 37 & $\begin{array}{r}888 \\
(18,7)\end{array}$ & 1507 & 99 \\
\hline $60-69$ & $708(12,1)$ & $111(9,8)$ & 184 & 14 & $\begin{array}{r}597 \\
(12,6)\end{array}$ & 1096 & 77 \\
\hline $70-79$ & $465(7,9)$ & $43(3,8)$ & 115 & 7 & $422(8,9)$ & 913 & 76 \\
\hline $80-89$ & $270(4,6)$ & $7(0,6)$ & 147 & 4 & $263(5,6)$ & 1509 & 113 \\
\hline $90+$ & $79(1,4)$ & $3(0,3)$ & 208 & 9 & $76(1,6)$ & 2536 & 119 \\
\hline Totalt & $\begin{array}{r}5870 \\
(100,0)\end{array}$ & $\begin{array}{r}1128 \\
(100,0)\end{array}$ & 212 & 17 & $\begin{array}{r}4742 \\
(100,0)\end{array}$ & 1222 & 69 \\
\hline
\end{tabular}


Tilfellene ble rapportert fra alle fylker (figur 4). Av de 5071 (86\%) tilfellene der det var kjent i hvilket land man var blitt smittet, var 3458 (68 \%) smittet i Norge og 1613 (32\%) i utlandet. Importerte smittetilfeller kom hovedsakelig fra Østerrike (702, 44\%), Spania (348, $22 \%$ ) og Italia $(171,11 \%)$. De resterende 370 tilfellene der vi hadde spesifikk informasjon om smitteland ( $23 \%$ ), hadde blitt eksponert i 45 forskjellige land. Fra periode A til periode B falt andelen smittet i utlandet fra $66 \%$ til $18 \%$, mens andelen tilfeller smittet i Norge økte fra $29 \%$ til $66 \%$ (tabell 1). Blant dem som hadde vært i Spania, var alderen høyere sammenlignet med alle øvrige reisende (median alder 72 år, mot 46 år) og andelen innlagte i sykehus større (94 tilfeller (27\%), mot 97 tilfeller ( $8 \%)$ ).
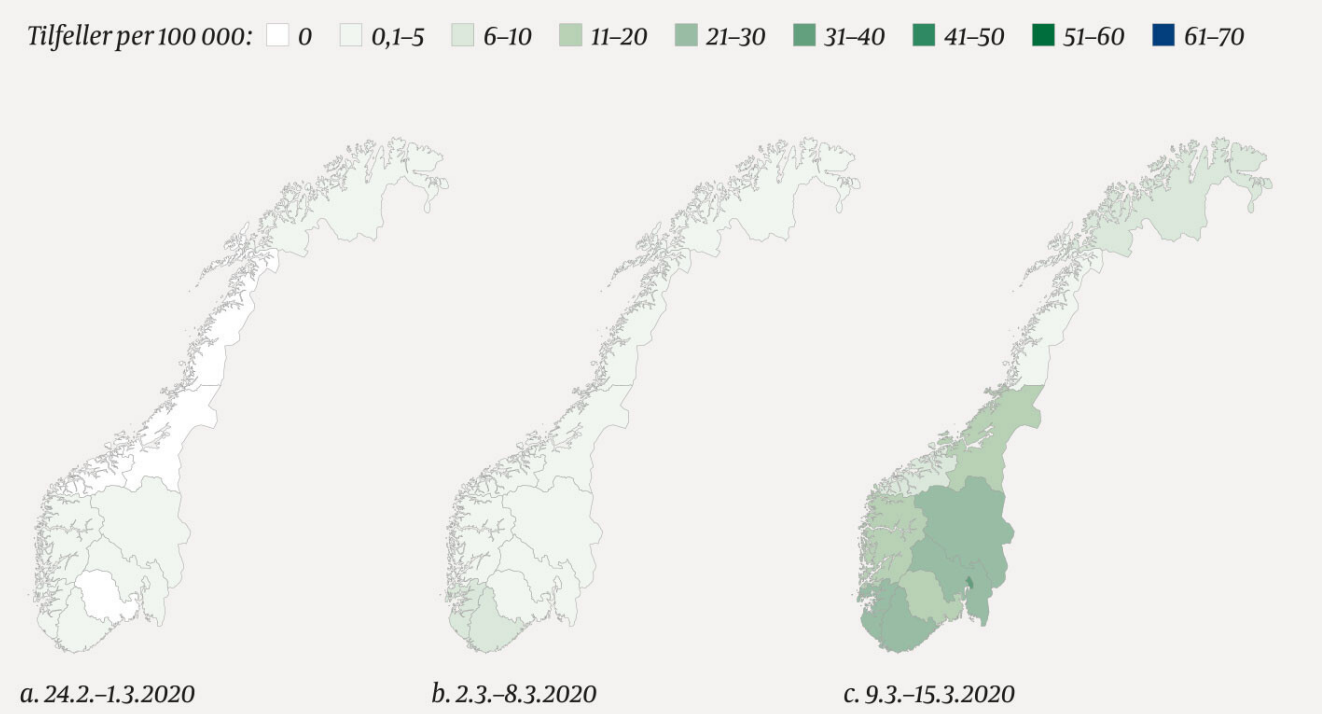

$\begin{array}{lll}\text { a. } 24.2 .-1.3 .2020 & \text { b. } 2.3 .-8.3 .2020 & \text { c. } 9.3 .-15.3 .2020\end{array}$

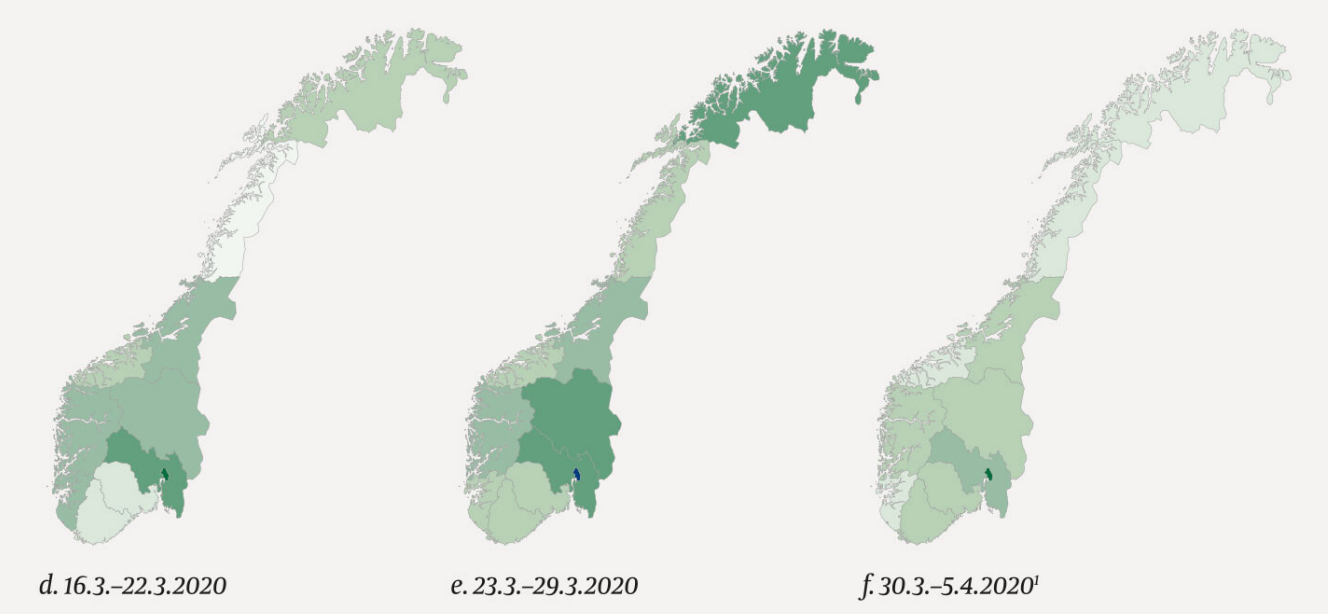

${ }^{1}$ Dataene er ikke komplette for uke 30.3.-5.4.2020

Figur 4 Ukentlig antall tilfeller av covid-19 per 100 ooo innbyggere etter bostedsfylke i Norge og prøvetakingsuke i perioden 24.2.-5.4.2020. Totalt antall tilfeller var 5870. Dato for rapportert symptomdebut var tilgjengelig for 4882 (83\%) av tilfellene. Første dato for symptomdebut som kan tilskrives covid-19, var 12. februar. Median intervall mellom symptomdebut og dato for prøvetaking var fire dager og $ø$ kte fra to dager i periode A til fem dager i periode B (tabell 1). Median intervall mellom testing og rapportering var én dag, og ingen forskjell ble observert mellom de to tidsperiodene.

Den første covid-19-relaterte sykehusinnleggelsen ble registrert 6. mars, og det første dødsfallet 12. mars. 750 (13\%) av tilfellene var inneliggende ved rapporteringstidspunktet. Andelen inneliggende ved rapporteringstidspunktet $ø$ kte fra $6 \%$ blant tilfellene i periode A 
til 14 \% blant tilfellene i periode B. 158 dødsfall (3\% totalt) ble rapportert innen 7. mai. Fem $(<1 \%)$ av tilfellene som ble testet frem t.o.m. 12. mars, døde. Andelen tilfeller med dødelig utfall, økte deretter til $3 \%$.

\section{Diskusjon}

I løpet av de første seks ukene av covid-19-utbruddet i Norge ble omtrent $2 \%$ av befolkningen testet for SARS-CoV-2, $5 \%$ av prøvene var positive og 5870 tilfeller ble rapportert til Folkehelseinstituttet.

Covid-19-epidemien inntraff i Norge under vintersesongens forkjølelses- og influensautbrudd. Til tross for at diagnostikk for covid-19 var tidlig på plass og hurtig ble oppskalert, var det derfor nødvendig med tydelige testkriterier for å ikke overskride testkapasiteten. I begynnelsen av utbruddet var strategien å fange opp alle introduksjoner av covid-19-smitte til Norge, først og fremst knyttet til utenlandsreise. Utbruddets begynnelse i Norge sammenfalt med stor reiseaktivitet til utlandet i vinterferieukene, og mange av de påviste tilfellene var menn i alderen 40-6o år som hadde vært på skiferie i Italia eller Østerrike.

I opptakten til 12. mars økte andelen innenlandssmittede, og antall tilfeller uten kjent smittevei økte. Det ble vurdert at Norge var over i en ny fase av pandemien (144). Da de omfattende kontrolltiltakene ble innført 12. mars, ble testkriteriene samtidig dreid mot å fange opp tilfeller av alvorlig covid-19, slik at sykdom etter utenlandsreise ikke lenger alene kvalifiserte til testing. Begrensningene gitt av testkriteriene har trolig medført at noen personer med smitte ikke ble diagnostisert.

Fra og med 13. mars endret aldersfordelingen seg blant de rapporterte tilfellene, og en høyere andel ble innlagt i sykehus eller døde. I vårt datagrunnlag ble sykehusinnleggelse registrert ved rapportering. Ut fra median tidsintervall mellom symptomdebut og sykehusinnleggelse og/eller død er det mulig at noen tilfeller ble innlagt i sykehus etter rapportering eller døde etter 7. mai. Det totale antallet sykehusinnleggelser er imidlertid i tråd med tallene fra Norsk intensiv- og pandemiregister (15). Selv om reisehistorie fra og med 13. mars ikke lenger var blant forutsetningene for testing, ble et stort antall tilfeller med reisehistorie til Spania rapportert i ukene etterpå. Mange av disse personene ble sannsynligvis testet på grunn av høy alder og/eller økt risiko for alvorlig sykdom og ikke primært på grunn av reisen. Dette eksempelet avdekker at det er en skjevhet i registrert informasjon om smitteland ut fra gjeldende testkriterier.

Andelen tilfeller blant helsepersonell var høyere i siste del av studieperioden, men bør tolkes med forsiktighet på grunn av manglende data. For de fleste av helsepersonell var $\mathrm{i}$ tillegg type eksponering og yrkesutøvelsen (f.eks. pasientkontakt) ukjent. Tallene kan derfor ikke benyttes som et mål på hvor mange som ble eksponert på jobb. Mer pålitelige tall for dette kan trolig skaffes gjennom forbedring av overvåkingssystemene. Vi fant også at andelen kvinner blant tilfellene var høyere enn andelen menn etter 12. mars. Dette kan skyldes $\emptyset$ kt testing blant helsepersonell og eldre, grupper med en relativt større andel kvinner (므).

Median intervall mellom symptomdebut og testing økte fra 13. mars. Dette kan skyldes testing rettet mot personer med alvorlig sykdom, noe som tar litt tid å utvikle, eller kan være et resultat av lokal praksis og testkapasitet. Diskrepansen mellom antall positive prøver og antall rapporterte tilfeller skyldes at noen tilfeller var registrert i laboratorieovervåkingssystemet med flere positive prøver grunnet gjentatt testing, og at noen tilfeller testet t.o.m. 5. april først ble rapportert i etterkant. Det var imidlertid svært liten forsinkelse mellom testing og rapportering i hele studieperioden. Data rapportert til Utbruddsregisteret og MSIS betraktes derfor som en tidsriktig kilde til informasjon om status for utbruddet, også tidlig i epidemien. Informasjonen om tilfellene ble maksimert 
ved å koble data fra MSIS-registeret med data fra Utbruddsregisteret, mens informasjon om antall testede fra Nasjonalt referanselaboratorium var viktig for å forstå svingningene i positivraten i lys av testaktivitet.

Antallet registrerte tilfeller i de tre datakildene vil ikke vise det sanne antallet smittede med SARS-CoV-2 i befolkningen. Det er kun laboratoriebekreftede tilfeller som meldes. Det kan ikke utelukkes at det forekom smitte i Norge tidligere enn 26. februar, da det ble rapportert at et tilfelle hadde symptomer som kunne tilskrives covid-19 allerede 12. februar. Videre var testkriteriene slik i perioden at kun de med symptomer oppfylte testkriteriene, og en stor andel covid-19-tilfeller er asymptomatiske eller har kun milde symptomer (17., 18). En storstilt testing av asymptomatiske eller presymptomatiske ville medført et betydelig ressursbehov, med $ø$ kt fare for falskt positive og falskt negative prøvesvar. Selv om diskrepansen mellom antall registrerte tilfeller og den sanne forekomsten av smittede i befolkningen er ukjent, er det grunn til å tro at smitteutbredelsen i Norge i studieperioden var relativt lav sammenlignet med situasjonen i mange andre land (19). Seroprevalensen (andelen med antistoffer) i Norge ble i midten av april beregnet til å være rundt $1 \%(\underline{\mathbf{2 0}})$.

\section{KONKLUSJON}

Tilgang til tidsriktige overvåkingsdata har vært avgjørende for å kunne følge utbruddet. Sammenstillingen av data fra ulike kilder har bidratt til et mer helhetlig bilde av utbruddets begynnelse og utvikling. Blant tilfellene av covid-19 rapportert til Folkehelseinstituttet de seks første ukene av epidemien ble det funnet forskjeller i fordelingen av alder, kjønn, smittested og alvorlighetsgrad i perioden før og etter 12. mars, da de omfattende kontrolltiltakene ble innført. Mens noen av disse forskjellene kan skyldes ulike faser av epidemien, er det viktig at funnene tolkes i lys av testkriterier, testaktivitet, kontrolltiltak og egenskaper ved overvåkingssystemene. For å få både bredere og mer detaljert kunnskap om forhold som omfang og utvikling av epidemien i Norge, hvor og i hvilke sammenhenger smitte skjer og hvem som har størst risiko for alvorlig sykdom, kreves supplerende undersøkelser, informasjon fra flere datakilder og videreutvikling av overvåkingssystemene. Gode overvåkingsdata med muligheter for kobling til ulike datakilder er helt sentralt for oppfølging av dagens strategi, som går ut på at smitte skal oppdages tidlig og håndteres lokalt med målrettede tiltak.

Artikkelen er fagfellevurdert.

Vi vil takke kommuneoverlegene og medisinsk mikrobiologiske laboratorier for rapportering av tilfeller og testresultater til Folkehelseinstituttet. Vi vil også takke alle ved Folkehelseinstituttet som har vart involvert i håndteringen av utbruddet. I tillegg vil vi takke Lisa Hansen for verdifulle innspill til manuskriptet og Torstein Aune for arbeidet med laboratorieovervåkingsdataene.

\section{LITTERATUR}

1. World Health Organization. Novel Coronavirus - China. https://www.who.int/csr/don/12-january2020-novel-coronavirus-china/en/ Lest 3.4.2020.

2. World Health Organization. WHO Director-General's opening remarks at the media briefing on COVID-19, 11.3.2020. https://www.who.int/director-general/speeches/detail/who-director-general-sopening-remarks-at-the-media-briefing-on-covid-19---11-march-2020 Lest 3.4.2020.

3. Regjeringen. Nasjonale tiltak. https://www.regjeringen.no/no/tema/koronavirus/nasjonaletiltak/id2693684/ Lest 1.5.2020.

4. Folkehelseinstituttet. Statistikk om koronavirus og covid-19. https://www.fhi.no/sv/smittsommesykdommer/corona/dags--og-ukerapporter/dags-og-ukerapporter-om-koronavirus/ Lest 27.5.2020. 
5. Corman VM, Landt O, Kaiser M et al. Detection of 2019 novel coronavirus (2019-nCoV) by real-time RT-PCR. Euro Surveill 2020; 25: 2000045. [PubMed][CrossRef]

6. Folkehelseinstituttet. Molekylær diagnostikk av Sars-Cov-2.

https://www.fhi.no/nettpub/coronavirus/testing-og-oppfolging-av-smittede/molekylar-diagnostikk/ Lest 11.8.2020.

7. FOR-2007-12-21-1573. Forskrift om varsling av og tiltak ved alvorlige hendelser av betydning for internasjonal folkehelse mv. (IHR-forskriften). https://lovdata.no/dokument/SF/forskrift/2007-12-211573 Lest 4.6.2020.

8. FOR-2003-06-20-740. Forskrift om Meldingssystem for smittsomme sykdommer (MSIS-forskriften). https://lovdata.no/dokument/SF/forskrift/2003-06-20-74o?q=MSIS Lest 4.6.2020.

9. FOR-2020-01-31-92. Forskrift om endring i forskrift om allmennfarlige smittsomme sykdommer og forskrift om Meldingssystem for smittsomme sykdommer

https://lovdata.no/dokument/LTI/forskrift/2020-01-31-92 Lest 4.6.2020.

10. Folkehelseinstituttet. Meldingskriterier for sykdommer i MSIS.

https://www.fhi.no/publ/2017/meldingskriterier-for-sykdommer-i-msis/ Lest 1.5.2020.

11. Folkehelseinstituttet. MSIS meldingsskjema. Nominativ melding om smittsom sykdom. https://www.fhi.no/publ/2019/msis-meldingsskjema.-nominativ-meld/ Lest 1.5.2020.

12. LOV-20oo-o6-23-56. Lov om helsemessig og sosial beredskap (helseberedskapsloven). https://lovdata.no/dokument/NL/lov/200o-o6-23-56 Lest 4.6.2020.

13. LOV-1994-08-05-55. Lov om vern mot smittsomme sykdommer (smittevernloven). https://lovdata.no/dokument/NL/lov/1994-08-05-55 Lest 4.6.2020.

14. Covid-19-epidemien: Risikovurdering og respons i Norge - Versjon 3. Oslo: Folkehelseinstituttet, 2020. https://www.fhi.no/publ/2020/covid-19-epidemien-risikovurdering/ Lest 28.8.2020.

15. COVID-19 Ukerapport - uke 19. Oslo: Folkehelseinstituttet; 2020.

https://www.fhi.no/publ/2020/koronavirus-ukerapporter/ Lest 4.6.2020.

16. Statistisk sentralbyrå. Helse- og sosialpersonell. https://www.ssb.no/arbeid-oglonn/statistikker/hesospers Lest 18.5.2020.

17. The Novel Coronavirus Pneumonia Emergency Response Epidemiology Team. The epidemiological characteristics of an outbreak of 2019 novel Coronavirus Diseases (COVID-19) China, 2020. China CDC Weekly 2020; 2: 113-22. [CrossRef]

18. Oran DP, Topol EJ. Prevalence of asymptomatic SARS-CoV-2 infection: A narrative review. Ann Intern Med 2020; 173:362-7. [PubMed][CrossRef]

19. European Centre for Disease Prevention and Control. Situation updates on COVID-19. https://www.ecdc.europa.eu/en/covid-19/situation-updates Lest 1.9.2020.

20. Tunheim GKA, Rø G, Steens A et al. Seroprevalence of SARS-CoV-2 in the Norwegian population measured in residual sera collected in April/May 2020 and August 2019. Oslo: Folkehelseinstituttet, 2020. https://www.fhi.no/publ/2020/seroprevalence-of-sars-cov-2-in-the-norwegian-population-measured-in-resid/ Lest 11.8.2020.

Publisert: 11. desember 2020. Tidsskr Nor Legeforen. DOI: 10.4045/tidsskr.20.0525

Mottatt 11.6.2020, første revisjon innsendt 1.9.2020, godkjent 21.10.2020.

Publisert under åpen tilgang CC BY-ND. Lastet ned fra tidsskriftet.no 26. april 2023. 